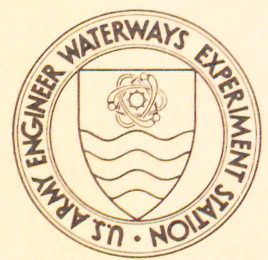

\title{
EVALUATION OF MARSH /ESTUARINE WATER QUALITY AND ECOLOGICAL MODELS: AN INTERIM GUIDE
}

by

Ross W. Hall, Jr.

Environmental Laboratory

U. S. Army Engineer Waterways Experiment Station

P. O. Box 631, Vicksburg, Miss. 39180

January 1982

Final Report

Approved For Public Release; Distribution Unlimited

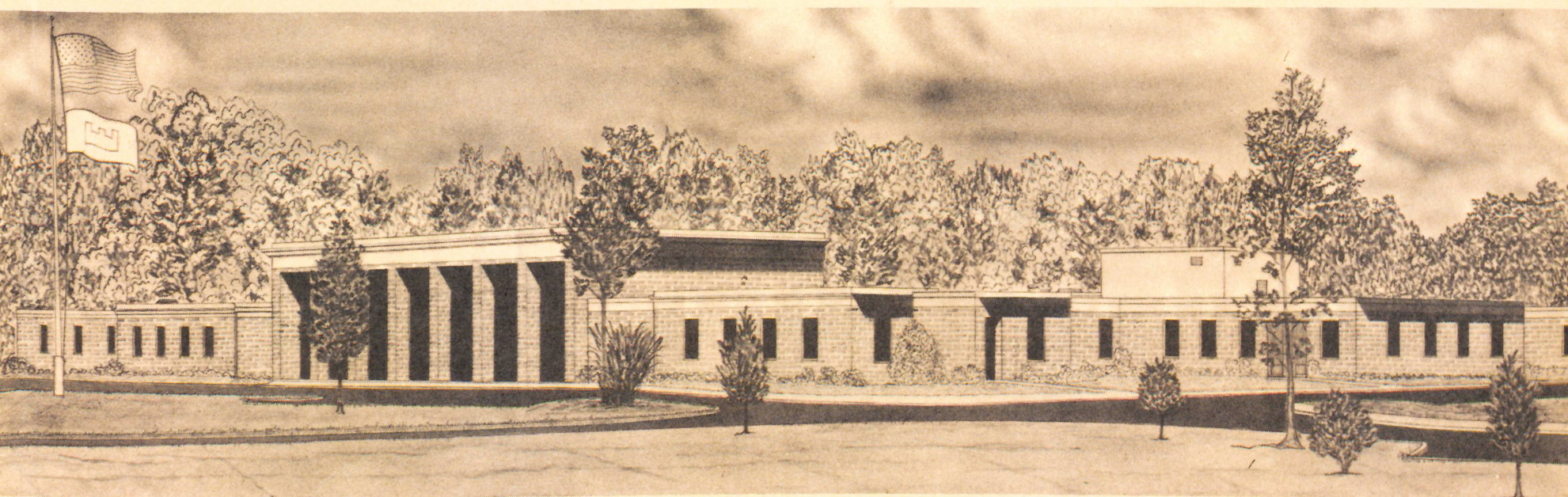

Prepared for Office, Chief of Engineers, U. S. Army

Washington, D. C. 20314 
$218288 \% \quad C .2$

Unclassified

SECURITY CLASSIFICATION OF THIS PAGE (Whon Data Entorod)

\begin{tabular}{|c|c|c|}
\hline \multicolumn{2}{|c|}{ REPORT DOCUMENTATION PAGE } & $\begin{array}{l}\text { READ INSTRUCTIONS } \\
\text { BEFORE COMPLETING FORM }\end{array}$ \\
\hline $\begin{array}{l}\text { 1. REPORT NUMBER } \\
\text { Miscellaneous Paper EL-82-1 }\end{array}$ & 2. GOVT ACCESSION NO. & 3. RECIPIENT'S CATALOG NUMBER \\
\hline \multirow{2}{*}{\multicolumn{2}{|c|}{$\begin{array}{l}\text { 4. TITLE (and Subtitie) } \\
\text { EVALUATION OF MARSH/ESTUARINE WATER QUALITY AND } \\
\text { ECOLOGICAL MODELS: AN INTERIM GUIDE }\end{array}$}} & $\begin{array}{l}\text { 5. TYPE OF REPORT \& PERIOD COVERED } \\
\text { Final report }\end{array}$ \\
\hline & & 6. PERFORMING ORG. REPORT NUMBER \\
\hline \multicolumn{2}{|l|}{$\begin{array}{l}\text { 7. AUTHOR(o) } \\
\text { Ross W. HaI1, Jr. }\end{array}$} & 8. CONTRACT OR GRANT NUMBER(B) \\
\hline \multicolumn{2}{|c|}{$\begin{array}{l}\text { 9. PERFORMING ORGANIZATION NAME AND ADDRESS } \\
\text { U. S. Army Engineer Waterways Experiment Station } \\
\text { Environmenta1 Laboratory } \\
\text { P. O. Box } 631 \text {, Vicksburg, Miss. } 39180\end{array}$} & $\begin{array}{l}\text { 10. PROGRAM ELEMENT' PROJECT, TASK } \\
\text { AREA \& WORK UNIT'NUMBERS }\end{array}$ \\
\hline \multirow{2}{*}{\multicolumn{2}{|c|}{$\begin{array}{l}\text { 11. CONTROLLING OFFICE NAME AND ADDRESS } \\
\text { Office, Chief of Engineers, U. S. Army } \\
\text { Washington, D. C. } 20314\end{array}$}} & $\begin{array}{l}\text { 12. REPORT DATE } \\
\text { January } 1982\end{array}$ \\
\hline & & $\begin{array}{l}\text { 13. NUMBER OF PAGES } \\
24\end{array}$ \\
\hline \multirow{2}{*}{\multicolumn{2}{|c|}{ 14. MONITORING AGENCY NAME ADDRESS(If different from Controlling Ollico) }} & $\begin{array}{l}\text { 15. SECURITY CLASS. (of this roport) } \\
\text { Unclassified }\end{array}$ \\
\hline & & $\begin{array}{l}\text { 15a. DECLASSIFICATION/DOWNGRADING } \\
\text { SCHEDULE }\end{array}$ \\
\hline
\end{tabular}

17. DISTRIBUTION STATEMENT (of tho abstract ontored In Block 20, if different trom Roport)

18. SUPPLEMENTARY NOTES

Available from National Technical Information Service, 5285 Port Royal Road, Springfield, Va: 22151.

19. KEY WORDS (Continue on revorse side if necessary and idontlly by block number)

Estuaries

Marshes

Mathematical mode1s

Water quality

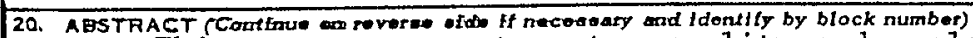

This report presents water quality and ecological problems in coastal marshes and estuaries, suggests applicable modeling approaches to problem solution, and provides the basis for the modeling recommendations through a brief summary of water quality and ecological modeling in the marsh/estuarine environment. 
Unclassified

SECURITY CLASSIFICATION OF THIS PAGE(Whon Data Entorod)

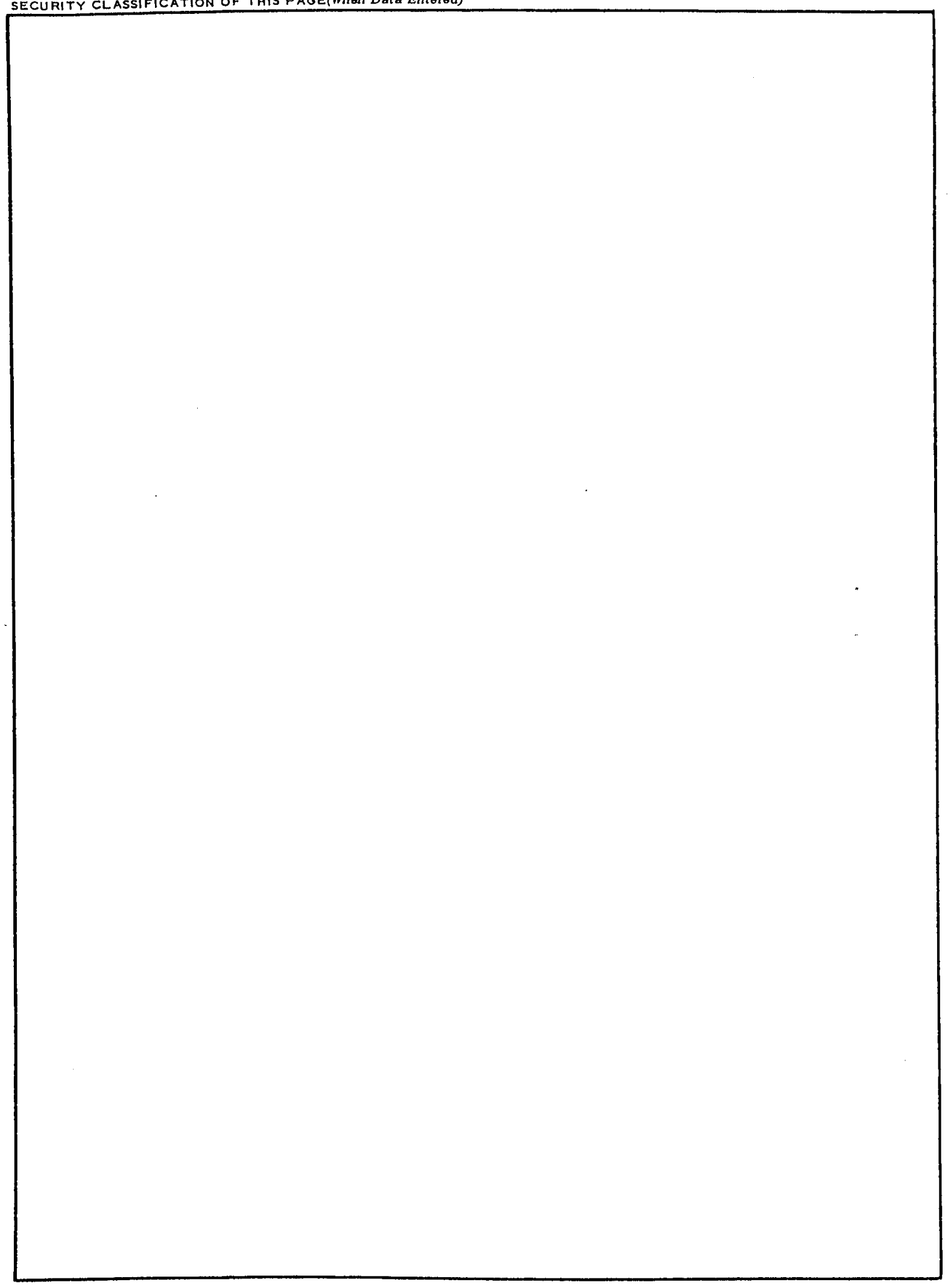

Unclassified

SECURITY CLASSIFICATION OF THIS PAGE(When Data Entered) 


\section{Preface}

This report represents a summarization of Corps of Engineers (CE) field office problems in estuaries and intertidal wetlands, a review of marsh/estuarine water quality and ecological models, and an evaluation of the applicability of mathematical modeling methodologies to environmental assessments in estuaries and intertidal wetlands.

The contents of this report were abstracted from the following publications:

Hamilton, P. 1980. "Survey of Marine Wetland and Estuarine Water Quality and Ecological Problems in Corps of Engineers Field Offices," Miscellaneous Paper EL-80-2, U. S. Army Engineer Waterways Experiment Station, CE, Vicksburg, Miss.

Hamilton, P. 1980. "Marine Wetland and Estuarine Processes and Water Quality Modeling; Workshop Report and Recommendations," Miscellaneous Paper EL-80-3, U. S. Army Engineer Waterways Experiment Station, CE, Vicksburg, Miss.

Hamilton, P., and Fucik, K. W. 1980. "Literature Review of Marine Wetland and Estuarine Water Quality and Ecosystem Models," Technical Report EL-80-5, U. S. Army Engineer Waterways Experiment Station, $\mathrm{CE}$, Vicksburg, Miss.

Hamilton, P., and Macdonald, K. B., eds. 1980. Estuarine and Wetland Processes; with Emphasis on Modeling, Plenum Press, New York.

The study was sponsored by the office, Chief of Engineers, U. S. Army, under the Environmental Impact Research Program.

Mr. Ross W. Hall, Jr., prepared this report under the supervision of Mr. Donald L. Robey, Chief, Ecosystems Research and Simulation Division, and Dr. John Harrison, Chief, Environmenta1 Laboratory, U. S. Army Engineer Waterways Experiment Station (WES), Vicksburg, Miss.

Commanders and Directors of WES during the preparation of this report were COL Nelson $\mathrm{P}$. Conover, $\mathrm{CE}$, and COL Tilford C. Creel, CE. Technical Director was Mr. F. R. Brown. 
Preface . . . . . . . . . . . . . . . . . . . . . . . . 1

Purpose and Scope . . . . . . . . . . . . . . . . . . . . . . . . 3

Water Quality and Ecological Problems . . . . . . . . . . . . . 3

Marine wetlands . . . . . . . . . . . . . . . . 3

Coastal zone . . . . . . . . . . . . . . . . . . 4

Environmental monitoring . . . . . . . . . . . . . . . . 4

Marsh/Estuarine Water Quality and Ecological Models . . . . . . . 4

Hydrodynamic models . . . . . . . . . . . . . . . . 5

Water quality and ecological models . . . . . . . . . . 8

References . . . . . . . . . . . . . . . . . . . 12

Tables 1-5 


\section{Purpose and Scope}

1. This report introduces marsh/estuarine water quality and ecological models and assists in evaluating the applicability of mathematical modeling methodologies to environmental assessments in estuaries and intertidal wetlands. This report provides preliminary guidance to District planners, engineers, and resource managers.

2. A brief summary of water quality and ecological modeling in the marsh/estuarine environment is provided as the basis for the modeling recommendations.

\section{Water Quality and Ecological Problems}

3. A survey of Corps of Engineers (CE) field offices with coastal responsibilities identified existing and anticipated water quality and ecological problems associated with CE activities in coastal marshes and estuaries. Existing and potential problems were classified and tabulated as to marine wetlands, coastal zone, and environmental monitoring (Table 1). The feasibility of numerical modeling techniques for addressing each identified problem is noted. A more detailed description of applicable modeling approaches is outlined in Table 2.

Marine wetlands

4. Mathematical modeling methodologies are not sufficiently developed to address the marine wetlands problems. Existing research is quantifying material cycling and primary and secondary production within the marsh and between the marsh and adjacent coastal waters. Existing mathematical models addressing these phenomena are research tools and are not suitable for planning and management.

5. Conceptual models should be used to guide studies that provide increased understanding and quantification. The potential applicability 
of marsh and estuarine ecosystem models to these problems suggests that studies be designed to understand important processes and to provide data for future model verification.

Coastal zone

6. Mathematical modeling techniques are not suitable for coastal zone problems 12 and 13 (Table 1). However, mathematical models can be applied to problems 14-16 when used in conjunction with complementary study procedures.

7. Present mathematical modeling studies address the fate of dredged material. Mathematical modeling to assess the environmental effects of turbidity resulting from dredging and disposal is not recommended at this time (problem 14).

8. Problems 15 and 16 are directly addressable through mathematical modeling. However, a more detailed understanding of the hydrodynamics of very shallow waters-including sheet flow in marshes; flow in very shallow channels; sediment transport; periodic inundation; and the relationships of residence time to winds, tides, and freshwater inflow and rainfal1--is needed. Present understanding of biological and chemical processes would limit simulations to assessing excessive algal growth and dissolved oxygen relationships. Additional knowledge would be required to simulate the cycling of toxic constituents. Environmental monitoring

9. Mathematical modeling methodologies are not appropriate to address environmental monitoring problems.

\section{Marsh/Estuarine Water Quality and Ecological Models}

10. District planners, engineers, and resource managers require an understanding of the behavior of marsh/estuarine ecosystems and how the system would respond as a result of future $C E$ activities.

11. One way to assess the effects of proposed activities is to make the actual changes in the system and directly observe the effects; however, such direct experimentation is usually impractical. An alternative is to model the physical system in such a way that essential 
cause-and-effect relationships are maintained. The model may be a scaled physical representation or a mathematical description based on physical laws and empirical formulae.

12. In a mathematical model, the cause-and-effect relationships between system elements are represented by a set of mathematical equations. Mathematical models may vary from a few equations that can be solved by hand computation to hundreds of equations requiring the use of a digital computer. The complexity of the mathematical model selected depends largely on the questions to be asked about the behavior of the actual system.

13. Marshes and estuaries are complex interactive ecosystems. Salient features that contribute to their complexity are diverse topography, environmental gradients, and the large number of biological components.

14. No single model exists that can simulate all aspects of water quality and ecological processes in marsh/estuarine ecosystems. If such a model were developed, the resulting complexity, extensive data requirements, and cost of computation would make its use impractical. An alternative strategy is a wide variety of more specialized models developed to more effectively address particular aspects of water quality or ecosystem processes. This section of the report will review the types and uses of mathematical models.

Hydrodynamic models

15. The basis for water quality models and ecosystem models that use the principle of conservation of mass is a model of the circulation of the estuary. The circulation in a partially mixed estuary is mainly driven by the tide, river inflow, salinity gradient, and wind. It is now considered that, in many estuaries, all four forcing mechanisms are equally important in influencing the circulation and the transport of water quality constituents. Estuarine circulations are some of the most complex geophysical flows in existence.

16. Physical oceanography of estuaries is discussed in the texts by Dyer (1973), Officer (1976), and McDowe11 and 0'Connor (1977); symposia edited by Kjerfve (1978) and Hamilton and Macdonald (1980); and 
reviews by Liu and Leendertse (1978) and Hamilton and Fucik (1980).

17. One-dimensional models. One use of one-dimensional models that included an advection-dispersion equation was the study of salinity intrusion in an estuary (Stigter and Siemons 1967; Thatcher and Harleman 1972; Williams and West 1973). Neglect of the variation with depth of current and salinity meant that the upstream flux of salt due to density currents and mixing due to vertical phase differences in the tidal variations of current and salinity were lumped together in a onedimensional longitudinal dispersion coefficient. Because the dispersion coefficient varied among estuaries and was highly dependent upon riverflow and distance from the estuary mouth (Williams and West 1973), onedimensional models were difficult to use in a predictive mode in partially mixed estuaries. However, these models serve as the hydrodynamic basis for the majority of estuarine water quality models.

18. Two-dimensional models. Consideration of the depth dimension permits the inclusion of the majority of the fundamental physical processes that affect the advection and dispersion of water quality constituents. The first study demonstrating the importance of depth variation on currents and salinities was the steady-state analytical solution of Rattray and Hansen (1962). These equations were expanded to explicitly include the longitudinal salt balance (Hansen and Rattray 1965; Rattray 1967; Winter 1973; Festa and Hansen 1976).

19. Time-dependent equations for a partially mixed estuary were numerically solved by Hamilton (1975) and Blumberg (1975). The solution techniques were explicit with time steps of about 1 min. More recent semi-implicit methods permit time steps of about 30 min (Hamilton 1976; Wang and Kravitz 1980), thereby permitting wind-driven transients to be investigated (Wang 1980).

20. The vertically averaged equations of motion have been extensively used for storm surge modeling. Hinwood and Wallis (1975a, 1975b) provide a review of these models. Vertically averaged hydrodynamic models are now quite sophisticated employing variable grids and embedded subgrid features to handle complex geometry such as channels and barriers (Butler 1980; Reid et al. 1977; Reid, Vastano, and Reid 1977). 
21. A few investigators have included vertically integrated advection-dispersion equations for salinity and other water quality constituents. Leendertse and Gritton (1971) hindcasted water quality constituents in Jamaica Bay, N. Y., and Hess and White (1977) modeled the dispersal of a marked fluid released in Narragansett Bay, R. I.

22. Three-dimensional models. Three-dimensional models are very complex and only a few have been developed. The model by Leendertse and Liu (1975, 1977) uses explicit finite difference methods and thus is extremely costly in computer time for any lengthly simulation. Caponi. (1976) developed a time-dependent model that used the complete threedimensional Navier-Stokes equations instead of the Boissinesq approximation. However, in an application to Chesapeake Bay, the use of a relatively coarse grid may have resulted in some anomalous circulations. Wang (1980) proposed the use of semi-implicit methods and mode splitting for increasing the computational efficiency of three-dimensional models.

23. Summary. Table 3 provides examples of the hydrodynamic models discussed. The list is not exhaustive, but is intended to show the variety of approaches to the numerical modeling of estuarine hydrodynamics.

24. Many one- and two-dimensional models include salinity advection and dispersion. Some models use tidally averaged velocity as input to salinity transport models. Investigations by Harleman (1971) indicate differences between the results of tidally averaged and timedependent one-dimensional simulations of salinity transport. Furthermore, he concluded that the importance of the highly empirical longitudinal dispersion coefficient decreases as the accuracy of description of the advective motion increases.

25. The alternatives to using tidally averaged or net tidal veloc-. ities are to output the hydrodynamic computational results for subsequent input to salinity transport model or to embed the salinity transport equations within the hydrodynamic computations. Embedding permits coupling of the salinity gradient to the momentum equations. However, highly discretized hydrodynamic models have inherent stability problems requiring time steps on the order of seconds to minutes with maximum 
simulation periods of days, while water quality phenomena of interest such as salinity distribution and phytoplankton growth may require simulation periods on the order of weeks or months, and possibly longer. Water quality and ecological models

26. Water quality models. Historically, the analysis of water quality has concentrated on the DO and BOD due to waste loads. The majority of DO-BOD models evolved from the study by Streeter and Phelps (1925), who assumed that the balance between DO and BOD concentrations was the result of two processes: the reaeration of the water column and the consumption of DO in the oxidation of BOD.

27. Later modeling emphasis has been on extending and refining the Streeter-Phelps formulation by using a more generalized mass balance approach and by the inclusion of additional processes such as benthic oxygen demand, benthic scour and deposition, photosynthesis and respiration of aquatic plants, and nitrification (Dobbins 1964; 0'Connor 1967; Dresnack and Dobbins 1968; O'Connor and DiToro 1970; Grantham, Schaake, and Pyatt 1971; Whitehead and Young 1975).

28. The more comprehensive estuarine water quality models have been developed to include the nitrogen and phosphorus cycle and the lower trophic levels of phytoplankton and zooplankton (Chen and orlob 1972; Ditoro et al. 1977; Dahl-Madsen 1978).

29. Water quality modeling is discussed in the texts edited by James (1978); Canale (1976); Biswas (1976); and Hatzinger, Vanlelgveld, and Zoeteman (1978); and in review articles by DiToro et al. (1977); Hahn and Schreiner (1978); and O'Connor, Thomann, and DiToro (1977).

30. A few water quality modeling investigations of estuaries have addressed water quality constituents other than DO-BOD, nitrogen, phosphorus, and the lower trophic levels of the biological community. A number of investigators have modeled the algal nutrient silica (Festa and Hansen 1976; Peterson, Festa, and Conomos 1978; Rattray and Officer 1979).

31. Nihoul et al. (1979) and Billen and Smitz (1977) modeled selected chemical constituents in an estuary by assuming thermodynamic equilibrium. The variable controlling partitioning between constituents 
was redox potentials estimated by considering the oxygen budget. The authors admit that thermodynamic equilibrium is not necessarily fulfilled throughout the estuary.

32. There have been very few models simulating fate and effects of heavy metals. The fate of metals in estuaries is very complicated and unclear, involving adsorption-desorption reactions, flocculation, precipitation, sedimentation, and biological uptake. Jorgensen (1979) modeled heavy metals using the concept of trophic length level. The concept involved the consideration of a length scale introduced into the equations as an independent variable that represents the time a constituent remains in a particular trophic level.

33. Ecological models. In contrast to water quality models, ecological models are more descriptive, emphasizing exhaustiveness and resolution often to the limits of potential data availability. Ecological models include numerous biological species or species aggregates and emphasize food chain and species interactions.

34. Cushing (1975), in his book on marine ecology and fisheries, points out that, in marine ecological studies, the limiting nutrient concept has been abandoned with an increased emphasis placed on predatorprey relationships. Early marine ecosystem models concentrated on the nutrient-phytoplankton-zooplankton interactions with complex formulations describing the transfer of material between the components (Steele 1974). Early investigations did not include explicit spatial variations, but more recent studies allow both spatial and temporal variability in systems which have large physical gradients such as upwelling regions (Walsh 1971; 0'Brien and Wroblewski 1972) and estuaries (Winter, Banse, and Anderson 1975; Kremer and Nixon 1.978).

35. In contrast to the early marine models with few components but complex interactions is the approach advocated by patten (1968). Patten's approach uses very complex model structures that involve many species, but the interactions between components are generally simple, linear, and empirical. These models tend to be very theoretical since little data are available for calibration.

36. Estuarine ecological models. Few estuarine ecosytem models 
exist. Pomeroy et al. (1972) simulated phosphorus flux in several Georgia estuaries. Bahr (1974) simulated energy flux in Georgia oyster beds. Dame, Vernbert, and Bonne11 (]977) used a similar model for South Carolina oyster beds emphasizing sensitivity analysis. Show (1979) developed a hydrological-biological model to investigate zooplankton distributions in a Texas coast embayment. Ferguson and Adams (1979) simulated epifauna and juvenile fish of an eelgrass community to investigate their response to temperature.

37. The two most comprehensive ecological models of estuaries are those by Winter, Banse, and Anderson (1975) and Kremer and Nixon (1978). Winter, Banse, and Anderson simulated primary production for the central basin of Puget Sound, which is a deep fjord with strong stratification. The model of Kremer and Nixon was applied to Narragansett Bay, which is a shallow, wide, and partially mixed estuary. Both models were based on extensive investigations by many researchers over many years.

38. Marsh ecological models. Very few marsh ecological models exist. Wiegert and Wetzel (1979) developed a model of a Georgia Spartina marsh. The objective of model development was to describe the pathways and dynamics of carbon flow in the marsh. Hopkinson and Day (1977) simulated carbon and nitrogen flows in a Louisiana salt marsh.

39. Models have been developed to address specific components of the marsh. Nixon and Oviatt (1973) simulated diurnal Do in tidal creeks and embayments to investigate the effects of sewage input and temperature increases on the DO concentrations in the embayments. Reimold (1974) specifically addressed the effect on the Spartina system of perturbations to the marsh. Zieman and Odum (1978) simulated plant growth and succession on an estuarine salt marsh. Lugo, Sell, and Snedaker (1976) simulated mangrove production.

40. Summary. Table 4 provides a summary of the different approaches to water quality modeling. The list is not exhaustive but provides examples ranging from one-dimensional, tidally averaged DO-BOD models through two-dimensional, time-dependent models that include DoBOD, plant nutrients, and the lower trophic levels.

41. Table 5 summarizes water quality models modified or developed 
through grants by State and Federal water resource agencies and are thus readily available with user documentation.

42. The SEM and ESO01 models provide the one-dimensional, tidally averaged analytical solution initially discussed by O'Connor (1960). The DEM model, and the derived models RECEIV and RIVSCI, are based on the WRE Link-Node hydrodynamic model. The model is basically a onedimensional solution adapted to two-dimensional estuaries. The model has been characterized as a good descriptive tool but lacks a predictive capability. The ESTECO model was developed for the Texas Water Development Board and uses a two-dimensional, vertically averaged hydrodynamic model called HYDTID to generate a velocity field for the water quality module. The water quality module is based upon the concepts originally included in the DEM series of models.

43. In summarizing the review of marsh/estuarine water quality and ecological models, the following conclusions can be drawn:

a. Additional studies are needed to investigate the appropriate procedures to couple hydrodynamic and water quality models since the time scales of interest may differ.

b. The DO-BOD estuarine models are appropriate for investigating the assimilative capacity of estuaries to heavy organic enrichment. However, for mildly perturbed estuaries in which photosynthesis, algal respiration, decomposition, and mixing processes play dominant roles, the understanding and characterization of significant processes are less well known.

c. Models developed to address eutrophication due to nutrient enrichment have not been verified in most cases. These models are not capable of predicting absolute values under varying environmental conditions. These models may be useful in evaluating minor perturbations, such as increased nutrient loadings or turbidity. However, these perturbations cannot be catastrophic. Events that significantly alter the species composition presently cannot be evaluated through simulations.

d. Detailed mathematical ecological models presently are not sufficiently developed to be applicable to environmental impact analysis. The extensive data requirements exceed the capabilities of most specific project studies. 


\section{References}

Bahr, L. 1974. "Aspects of the Structure and Function of the Intertidal Oyster Reef Community in Georgia," Ph.D. Dissertation, University of Georgia, Athens, Ga.

Barrett, M. J., and Mallowney, B. M. 1972. "Pollution in Relation to the Thames Barrier," Philosophical Transactions of the Royal Society of London, A Mathematical and Physical Science, Vol 272, pp 213-221.

Billen, G., and Smitz, J. 1977. "Mathematical Models of Water Quality in a Highly Polluted Estuary," Hydrodynamics of Estuaries and Fjords,

Nihou1, J. C. J., ed., Elsevier, Amsterdam, pp 55-62.

Biswas, A. K., ed. 1976. Systems Approach to Water Management, McGrawHi11, New York.

Blumberg, A. F. 1975. "A Numerical Investigation Into the Dynamics of Estuarine Circulation," Technica1 Report 91, Chesapeake Bay Institute, Johns Hopkins University, Baltimore, Md.

Butler, H. L. 1978. "Coastal Flood Simulation in Stretched Coordinates," Proceedings of the Sixteenth International Conference on Coastal Engineering, American Society of Civil Engineers, Hamburg, Germany, 27 August-1 September 1978.

Butler, H. L. 1980. "Evolution of a Numerical Model for Simulating Long-Period Wave Behavior in Ocean-Estuarine Systems," Estuarine and Wetland Processes; with Emphasis on Modeling, Hamilton, P., and Macdonald, K. B., eds., Plenum Press, New York.

Callaway, R. J., Byram, K. V., and Ditsworth, G. R. 1969. "Mathematical Model of the Columbia River from the Pacific Ocean to Bonneville Dam, Part I: Theory, Program Notes, and Programs," Federal Water Pollution Control Administration, Pacific Northwest Water Laboratory, Corvallis, Oreg.

Callaway, R. J., and Byram, K. V. 1970. "Mathematical Model of the Columbia River from the Pacific Ocean to Bonneville Dam, Part II: InputOutput and Initial Verification Procedures," U. S. Environmental Protection Agency, Water Quality Office, Pacific Northwest Water Laboratory, Corvallis, Oreg.

Canale, R. P., ed. 1976. Modeling Biochemical Processes in Aquatic Ecosystems, Ann Arbor Science Publishers, Ann Arbor, Mich.

Caponi, E. A. 1976. "The Simulation of Estuarine Circulations With a Ful1y Three-Dimensional Numerica1 Mode1," Estuarine Processes, Vol 11, Wiley, M., ed., Academic Press, New York, pp 332-346.

Chapra, S. C., and Gordimer, S. 1973a. "ES001: A Steady-State, OneDimensional, Estuarine Water Quality Mode1," U. S. Environmental Protection Agency/Region 2, Data Systems Branch, New York. 
Chapra, S. C., and Gordimer, S. 1973b. "Addendum to ES001: Verification of Model for New York Harbor," U. S. Environmental Protection Agency/Region 2, Data Systems Branch, New York.

Chen, C. W., and Orlob, G. T. 1972. "Ecologic Simulation for Aquatic Environments, Report PB-218-828, Office of Water Resources Research, U. S. Environmenta1 Protection Agency, Washington, D. C.

Cushing, D. H. 1975. Marine Ecology and Fisheries, Cambridge University Press, Cambridge, United Kingdom.

Dahl-Madsen, K. E. 1978. "Mathematical Modeling of Eutrophied Coastal Areas," Progress in Water Technology, Vol 10, pp 217-235.

Dame, R. F., Vernbert, F. J., and Bonnell, R. J. 1977. "Analysis of the North Inlet Marsh-Estuarine Ecosystem," Helgolander Wissehschaftliche Meeresuntersuchungen, Vol 30, pp 343-356.

DiToro, D. M. et a1. 1977. "Estuarine Phytoplankton Biomass Models-Verification Analysis and Preliminary Applications," The Sea, Vol 6, Goldberg, E. D. et al., eds., Wiley-Interscience, New York, pp 969-1020.

Dobbins, W. E. 1964. "BOD and Oxygen Relationships in Streams," Proceedings, Journal of the Sanitary Engineering Division, American Society of Civil Engineers, Vol 80, No. SA3, pp 53-78.

Dresnack, R., and Dobbins, W. E. 1968. "Numerical Analysis of BOD and DO Profiles," Proceedings, Journal of the Sanitary Engineering Division, American Society of Civil Engineers, Vol 94, No. SA5, pp 789-807.

Dyer, K. R. 1973. Estuaries: A Physical Introduction, John Wiley and Sons, London.

Elliott, A. J. 1975. "A Steady State Two-Layered Non-Coupled Dynamic and Kinematic Estuarine Model with Application to the Potomac Estuary," Special Report 44, Chesapeake Bay Institute, Johns Hopkins University, Baltimore, Md.

Feigner, K. D., and Harris, H. S. 1970. "Documentation Report, FWQA Dynamic Estuary Mode1," U. S. Department of the Interior, Federa1 Water Quality Administration, Washington, D. C.

Ferguson, R. L., and Adams, S. M. 1979. "A Mathematical Model of Trophic Dynamics in Estuarine Seagrass Communities," Marsh-Estuarine Systems Simulation, Dame, R. F., ed., University of South Carolina Press, Columbia, S. C., pp $41-70$.

Festa, J. F., and Hansen, D. V. 1976. "A Two Dimensional Model of Estuarine Circulation: The Effects of Altering Depth and River Discharge," Estuarine and Coastal Marine Science, Vo1 4, pp 309-323.

Grantham, G. R., Schaake, J. C., and Pyatt, E. E. 1971. "Water Quality Simulation Model," Proceedings, Journal of the Sanitary Engineering Division, American Society of Civil Enginecrs, Vol 97, No. SA5, pp 569-585. 
Hahn, H. H., and Schreiner, H. 1978. "Water Quality Modeling," Progress in Water Technology, Vo1 10, pp 185-201.

Hamilton, P. 1975. "A Numerical Model of the Vertical Circulation of Tidal Estuaries and Its Application to the Rotterdam Waterway," Royal Astronomical Society Geophysical Journal, Vol 40, pp 1-21.

1976. "On the Numerical Formulation of a Time-Dependent Multi-Level Model of an Estuary, With Particular Reference to Boundary Conditions," Estuarine Processes, Vo1 2, Wiley, M., ed., Academic Press, New York, pp 347-363.

- 1980. "Survey of Marine Wetland and Estuarine Water Qua1ity and Ecological Problems in Corps of Engineers Field Offices," Miscellaneous Paper EL-80-2, U. S. Army Engineer Waterways Experiment Station, CE, Vicksburg, Miss.

Hamilton, P., and Fucik, K. W. 1980. "Literature Review of Marine Wetland and Estuarine Water Quality and Ecosystem Models," Technical Report EL-80-5, U. S. Army Engineer Waterways Experiment Station, CE,

Vicksburg, Miss.

Hamilton, P., and Macdonald, K. B., eds. 1980. Estuarine and Wetland Processes; with Emphasis on Modeling, Plenum Press, New York.

Hansen, D. V., and Rattray, M., Jr. 1965. "Gravitational Circulation in Straits and Estuaries," Journal of Marine Research, Vol 23, pp 104-122.

Harleman, D. R. F. 1971. "One-Dimensional Mode1s," Estuarine Modeling: An Assessment, Report by TRACOR to Environmental Protection Agency Water Quality Office, EPA 16070DZV02/71, pp 34-101, Washington, D. C.

Hatzinger, O., Vanlelgveld, I. H., and Zoeteman, B. C. J., eds. 1978. Aquatic Pollutants: Transformation and Biological Effects, Pergamon, Oxford, United Kingdom.

Hess, K. W., and White, F. M. 1977. "Modeling the Disposal of a Marked Fluid in Narragansett Bay," Marine Technical Report 38, Department of Ocean Engineering, University of Rhode Island, Kingston, R. I.

Hinwood, J. B., and Wallis, I. G. 1975a. "Classification of Models of Tidal Waters," Journal of the Hydraulics Division, American Society of Civil Engineers, Vol 101, No. HY10, pp 1315-1331.

- 1975b. "Review of Models of Tidal Waters," Journal of the Hydraulics Division, American Society of Civil Engineers, Vol 101, No. HYI1, pp 1405-1421.

Hodgins, D. O. 1979. "A Time-Dependent Two-Layer Model of Fjord Circulation and Its Application to Alberni Inlet, British Columbia," Estuarine and Coasta1 Marine Science, Vo1 8, pp 361-378.

Hopkinson, C. S., and Day, J. W. 1977. "A Model of the Barataria Bay Salt Marsh Ecosystem," Ecosystem Modeling in Theory and Practice, Hal1, C. A. S., and Day, J. W., eds., John Wiley and Sons, New York, pp 235-266. 
Hydroscience, Inc. 1971. "Simplified Mathematical Modeling of Water Quality," Report to Office of Water Programs, U. S. Environmental Protection Agency, Washington, D. C.

- 1972. "Addendum to Simplified Mathematical Modeling of Water Quality," Report to Office of Water Programs, U. S. Environmental Protection Agency, Washington, D. C.

James, A., ed. 1978. Mathematical Models in Water Pollution Control, Wiley-Interscience, New York.

Johns, B. 1978. "The Modeling of Tidal Flow in a Channel Using a Turbulence Energy Closure Scheme," Journal of Physical Oceanography, Vo1 8, pp 1042-1049.

Jorgensen, S. E. 1979. "Modeling the Distribution and Effects of Heavy Metals in an Aquatic Ecosystem," Ecological Modeling, Vo1 6, pp 199-222.

Kjerfve, B., ed. 1978. Estuarine Transport Processes, University of South Carolina Press, Columbia, S. C.

Kremer, J. N., and Nixon, S. W. 1978. A Coastal Marine Ecosystem: Simulation and Analysis, Springer-Verlag, New York.

Leendertse, J. J., and Gritton, E. C. 1971. "A Water-Quality Simulation Model for Well Mixed Estuaries and Coastal Seas: Vol II - Jamaica Bay Simulations," Report R-709-NYC, Rand Corporation, Santa Monica, Calif. Leendertse, J. J., and Liu, S-K. 1975. "A Three Dimensional Model for Estuaries and Coastal Seas: Vol II - Aspects of Computation,"

Report 5-1764-OWRT, Rand Corporation, Santa Monica, Calif.

- 1977. "A Three Dimensional Model for Estuaries and Coastal Seas: Vol IV - Turbulent Energy Computation," Report R-2187-OWRT, Rand Corporation, Santa Monica, Calif.

Liu, S-K., and Leendertse, J. J. 1978. "Multidimensional Numerical Modeling of Estuaries and Coastal Seas," Advances in Hydroscience, Vol 13, pp 96-164.

Lugo, A. E., Se11, M., and Snedaker, S. C. 1976. "Mangrove Ecosystem Analysis," Systems Analysis and Simulation in Ecology, Vol IV, Patten, B. C., ed., Academic Press, New York, pp 113-145.

McDowe11, D. M., and O'Connor, B. A. 1977. Hydraulic Behavior of Estuaries, John Wiley and Sons, New York.

Metcalf and Eddy, Inc., University of Florida, and Water Resources Engineers, Inc. 1971. "Storm Water Management Mode1, Vo1 I: Final Report," Water Pollution Research Series 11024 DOC 07/71, U. S. Environmental. Protection Agency, Water Quality Office, Washington, D. C.

Nihoul, J. C. J. et a1. 1979. "Hydrodynamic and Water Quality Mode1 of the Scheldt Estuary," Marsh-Estuarine System Simulation, Dame, R. F., ed., University of South Carolina Press, Columbia, S. C., pp 71-82.

Nixon, S. W., and Oviatt, C. A. 1973. "Ecology of a New England Salt Marsh," Ecological Monographs, Vo1 43, pp 463-498. 
O'Brien, J. J., and Wroblewski, J. S. 1972. "Analysis of a NutrientLimited Phytoplankton Mode1," Florida State University, Unpublished M.S., Tallahassee, Fla.

O'Connor, D. J. 1960. "Oxygen Balance of an Estuary," Proceedings, Journal of the Sanitary Engineering Division, American Society of Civil Engineers, Vol 86, No. SA3, pp 35-55.

O'Connor, D. J. 1967. "The Temporal and Spatial Distribution of Dissolved Oxygen in Streams," Water Resources Research, Vol 3, pp 65-79.

0'Connor, D. J., and DiToro, D. M. 1970. "Phytosynthesis and Oxygen Balance in Streams," Proceedings, Journal of the Sanitary Engineering Division, American Society of Civil Engineers, Vol 96, No. SA2, pp 547-571.

O'Connor, D. J., Thomann, R. V., and DiToro, D. M. 1977. "Water Quality Analyses of Estuarine Systems," Estuaries, Geophysics and the Environment, National Academy of Sciences, Washington, D. C., pp 71-83.

officer, C. B. 1976. Physical Oceanography of Estuaries (and Associated Coastal Waters), John Wiley and Sons, New York.

Patten, B. C. 1968. "Mathematical Models of P1ankton Production," Internationale Revue der Gesamten Hydrobiologie, Vol 53, pp 357-408.

Pearson, C. E., and Winter, D. F. 1977. "On the Calculation of Tidal Currents in Homogeneous Estuaries," Journal of Physical Oceanography, Vo1 7, pp 520-531.

Peterson, D. H., Festa, J. F., and Conomos, T. J. 1978. "Numerical Simulation of Dissolved Silica in San Francisco Bay," Estuarine and Coastal Marine Science, Vo1 7, pp 99-116.

Pomeroy, L. R. et a1. 1972. "Nutrient Flux in Estuaries," Limnology Oceanography Special Symposium, Vo1 1, pp 274-291.

Rattray, M., Jr. 1967. "Some Aspects of the Dynamics of Circulation in Fjords," Estuaries, Lauff, G. H., ed., American Association for the Advancement of Science, pp 52-62.

Rattray, M., Jr., and Hansen, D. V. 1962. A Similarity Solution for Circulation in an Estuary," Journal of Marine Research, Vol 20, pp 121-133.

Rattray, M., Jr., and Officer, C. B. 1979. "Distribution of a NonConservative Constituent in an Estuary with Application to the Numerical Simulation of Dissolved Silica in the San Francisco Bay," Estuarine and Coastal Marine Science, Vo1 8, pp 489-494.

Reid, R. 0. et al. 1977. "Experiment in Storm Surge Simulation," The Sea, Goldberg, E. D. et al., eds., John Wiley and Sons, New York, pp 393-406.

Reid, R. O., Vastano, A. C., and Reid, R. J. 1977. "Development of Surge II Program With Application to the Sabine-Calcasieu Area for Hurricane Carla and Design Hurricanes," Technica1 Paper No. 77-13, U. S. Army Engineer Coastal Engineering Research Center, Fort Belvoir, Va. 
Reimold, R. J. 1974. "Mathematical Modeling - Spartina," Ecology of Halophytes, Reimold, R. J., and Queen, W. H., eds., Academic Press, New York, pp 393-406.

Seip, K. L. 1979. "A Mathematical Model for the Uptake of Heavy Metals in Benthic Algae," Ecological Modeling, Vol 6, pp 183-197.

Seip, K. L. et al. 1979. "A Mathematical Model for the Distribution and Abundance of Benthic Algae in a Norwegian Fjord," Ecological Modeling, Vol 6, pp 133-166.

Show, I. T. 1979. "An Application of Compartmental Models to Meso-Scale Marine Ecosystems," Ecosystem Models, Statistical Ecology Series, Vol 10, Matis, J. H., Patten, B. C., and White, G. C., eds., International Cooperative Publication House, Burtonsville, Md., pp 73-97.

Steel, J. H. 1974. The Structure of Marine Ecosystems, Harvard University Press, Cambridge, Mass:

Stigter, C., and Siemons, J. 1967. "Calculation of Longitudinal Salt Distribution as a Function of Time," Delft Hydraulics, Lab. Pub1. No. 52.

Streeter, H. W., and Phelps, E. B. 1925. " $\Lambda$ Study of the Pollution and Natural Purification of the Ohio River," Bulletin No. 146, U. S. Public Health Service, Washington, D. C.

Systems Control, Inc., and Snohomish County Planning Department. 1974. "Water Quality Management Plan for the Snohomish River Basin and the Stillaguamish River Basin, Vol IV: Computer Program Documentation, Part B: Dynamic Estuary Model (SRMSCI)," Report by System Control, Inc., to Snohomish County Planning Department, Everett, Wash.

Texas Water Development Bóard. 1977. "ESTECO: Estuarine Aquatic Ecologic Mode1, Program Documentation and Users Manua1," Report by Water Resources Engineers, Inc., to Texas Water Development Board, Austin, Tex. Thatcher, M. L., and Harleman, D. R. F. 1972. "A Mathematical Model for the Prediction of Unsteady Salinity Intrusion in Estuaries," Technical Report No. 144, Ralph M. Parsons Laboratory for Water Resources and Hydrodynamics, Department of Civil. Engineering, Massachusetts Institute of Technology, Cambridge, Mass.

Walsh, J. J. 1971. "Relative Importance of Habitat Variables in Predicting the Distribution of Phytoplankton at the Ecotone of the Antarctic Upwelling System," Investigacion Pesqnera, Vo1 35, pp 309-330.

Wang, D-P. 1980. "Observation and Modeling of the Circulation in the Chesapeake Bay," Estuarine and Wetland Processes; with Emphasis on

Modeling, Hamilton, P., and Macdonald, K. B., eds., Plenum Press, New York.

Wang, D-P., and Kravitz, D. W. 1980. "A Semi-Implicit Two-Dimensiona1 Model of Estuarine Circulation," Journal of Physical Oceanography, Vol 10, pp 441-454.

Water Resources Engineers. 1974. "Computer Program Documentation for the Dynamic Estuary Mode1," prepared for the U. S. Environmental 
Protection Agency, Systems Development Branch, Washington, D. C.

Whitehead, P. G., and Young, P. C. 1975. "A Dynamic Stochastic Model for Water Quality in Part of the Bedford-Ouse River System," Computer Simulation of Water Resources Systems, North-Holland Publishing Co., Amsterdam, pp 417-438.

Wiegert, R. G., and Wetze1, R. C. 1979. "Simulation Experiment with a Fourteen-Compartment Model of a Spartina Salt Marsh," Marsh-Estuarine Systems Simulation, Dame, R. F., ed., University of South Carolina Press, Columbia, S. C., pp 7-39.

Williams, D. J. A., and West, J. R. 1973. "A One-Dimensional Representation of Mixing in the Tay Estuary," Water Pollution Research Technical Paper 13, Department of the Environment, Her Majesties Stationary office, London, pp 118-125.

Winter, D. F. 1973. "A Similarity Solution for Steady State Gravitational Circulation in Fjords," Estuarine and Coastal Marine Science, Vo1 1, pp 387-400.

Winter, D. F., Banse, K., and Anderson, G. C. 1975. "The Dynamics of Phytoplankton Blooms in Puget Sound, a Fjord in the Northwestern United States," Marine Biology, Vol 29, pp 139-176.

Zieman, J. C., and Odum, W. E. 1978. "Modeling of Ecological Succession and Production in Estuarine Marshes," Technical Report D-77-35, U. S. Army Engineer Waterways Experiment Station, CE, Vicksburg, Miss. 
Table 1

Existing and Potential Water Quality and Ecological Problems

Identified by a Survey of CE Field offices with

Coastal Responsibility

\begin{tabular}{|c|c|c|}
\hline Problem & Description & $\begin{array}{c}\text { Modeling } \\
\text { Feasibility } \\
\end{array}$ \\
\hline \multicolumn{3}{|c|}{ Marine Wetlands } \\
\hline 1 & Existing wetlands need to be surveyed. & -- \\
\hline 2 & $\begin{array}{l}\text { Problems are encountered when applying the } \\
\text { different kinds of available classifica- } \\
\text { tion schemes. }\end{array}$ & -- \\
\hline 3 & $\begin{array}{l}\text { Information is needed on the role of buffer } \\
\text { zones around wetlands. }\end{array}$ & -- \\
\hline 4 & $\begin{array}{l}\text { Wetland values need to be assessed by } \\
\text { productivity measurements. }\end{array}$ & -- \\
\hline 5 & $\begin{array}{l}\text { More information is needed on the manage- } \\
\text { ment of diked impoundments. }\end{array}$ & -- \\
\hline 6 & $\begin{array}{l}\text { More information is needed on the assini- } \\
\text { lation of effluent and dredged material } \\
\text { by the wetland. }\end{array}$ & -- \\
\hline 7 & $\begin{array}{l}\text { Delta growth as a means of marsh creation } \\
\text { needs to be investigated. }\end{array}$ & -- \\
\hline 8 & $\begin{array}{l}\text { Additional understanding of marsh creation } \\
\text { through dredged material disposal is } \\
\text { needed. }\end{array}$ & -- \\
\hline 9 & $\begin{array}{l}\text { Importance of created marsh on the total } \\
\text { bay-marsh ecosystem requires additional } \\
\text { study. }\end{array}$ & -- \\
\hline 10 & $\begin{array}{l}\text { Effects of changes in freshwater flow on } \\
\text { wetland areas need to be investigated. }\end{array}$ & -- \\
\hline 11 & $\begin{array}{l}\text { Procedures to evaluate the effects of } \\
\text { stresses on the wetlands such as plat- } \\
\text { forms and highway bridges need to be } \\
\text { developed. }\end{array}$ & -- \\
\hline & (Continued) & \\
\hline
\end{tabular}

* Entries in this column are defined as follows: -- mathematical modeling methodologies are not sufficiently developed to address the problem; $\checkmark$ modeling is feasible. 
Table 1 (Concluded)

\begin{tabular}{|c|c|}
\hline Problem & Description \\
\hline & Coastal Zone \\
\hline 12 & $\begin{array}{l}\text { Offshore disposal sites are needed due to a } \\
\text { lack of upland sites. }\end{array}$ \\
\hline 13 & Problems are encountered with bioassays. \\
\hline 14 & $\begin{array}{l}\text { Concerns exist over the effects of turbid- } \\
\text { ity produced by dredging and disposal } \\
\text { operations. }\end{array}$ \\
\hline 15 & $\begin{array}{l}\text { Water quality problems such as eutrophica- } \\
\text { tion or pollution exist in estuaries or } \\
\text { rivers. }\end{array}$ \\
\hline 16 & $\begin{array}{l}\text { Procedures for evaluating the impacts of } \\
\text { cumulative development of dead-end canals } \\
\text { small boat harbors, and marinas are } \\
\text { needed. }\end{array}$ \\
\hline \multirow[t]{2}{*}{17} & $\begin{array}{l}\text { Field offices need hydrodynamic and } \\
\text { advection-dispersion models. }\end{array}$ \\
\hline & Environmenta1 Monitoring \\
\hline 18 & $\begin{array}{l}\text { Methods of storing and handling data and } \\
\text { literature for environmental assessments } \\
\text { need to be modernized. }\end{array}$ \\
\hline 19 & $\begin{array}{l}\text { Longer lead times are needed for compre- } \\
\text { hensive studies for environmental impact } \\
\text { assessment. }\end{array}$ \\
\hline 20 & $\begin{array}{l}\text { More long-term monitoring is needed to per- } \\
\text { mit impact evaluations. }\end{array}$ \\
\hline 21 & $\begin{array}{l}\text { Long-term studies are needed to provide } \\
\text { additional understanding of problems } \\
\text { unique to the field office. }\end{array}$ \\
\hline 22 & $\begin{array}{l}\text { Exchange of technical information be- } \\
\text { tween field offices needs to be improved. }\end{array}$ \\
\hline
\end{tabular}

Modeling

Feasibility 
Table 2

Existing and Potential Water Quality and Ecological

Problems and Applicable Modeling Approaches

\begin{tabular}{|c|c|c|c|c|}
\hline \multirow[b]{3}{*}{ Problem } & \multicolumn{4}{|c|}{ App 11cable Modeling Approaches } \\
\hline & \multicolumn{2}{|c|}{ Water Quality } & \multicolumn{2}{|c|}{ Ecosystem } \\
\hline & DO-BOD & Phytop lankton & Marsh & Estuary \\
\hline \multicolumn{5}{|c|}{ Marine wetlands } \\
\hline \multicolumn{5}{|l|}{1} \\
\hline \multicolumn{5}{|l|}{2} \\
\hline \multicolumn{5}{|l|}{3} \\
\hline \multicolumn{5}{|l|}{4} \\
\hline 5 & * & * & $* *$ & \\
\hline 6 & & & ** & \\
\hline 7 & & & $* *$ & $* *$ \\
\hline 8 & & & $* *$ & $* *$ \\
\hline 9 & & & ** & $* *$ \\
\hline 10 & & & $* *$ & \\
\hline 11 & & & $* *$ & \\
\hline
\end{tabular}

Coastal zone

12

13

14

15

16

17

$\begin{array}{rr}* & * \\ * & * \\ * & * *\end{array}$

$* *$

$* *$

Environmental

monitoring

18

19

20

21

22

Note: $\quad$ DO = dissolved oxygen; $\mathrm{BOD}=$ biochemical oxygen demand.

* State of the art ready for application with only minor adaptations.

** State of the art not ready for application but development for selected purposes is feasible. 
Table 3

Representative Types of Hydrodynamic Mode1s of Estuaries*

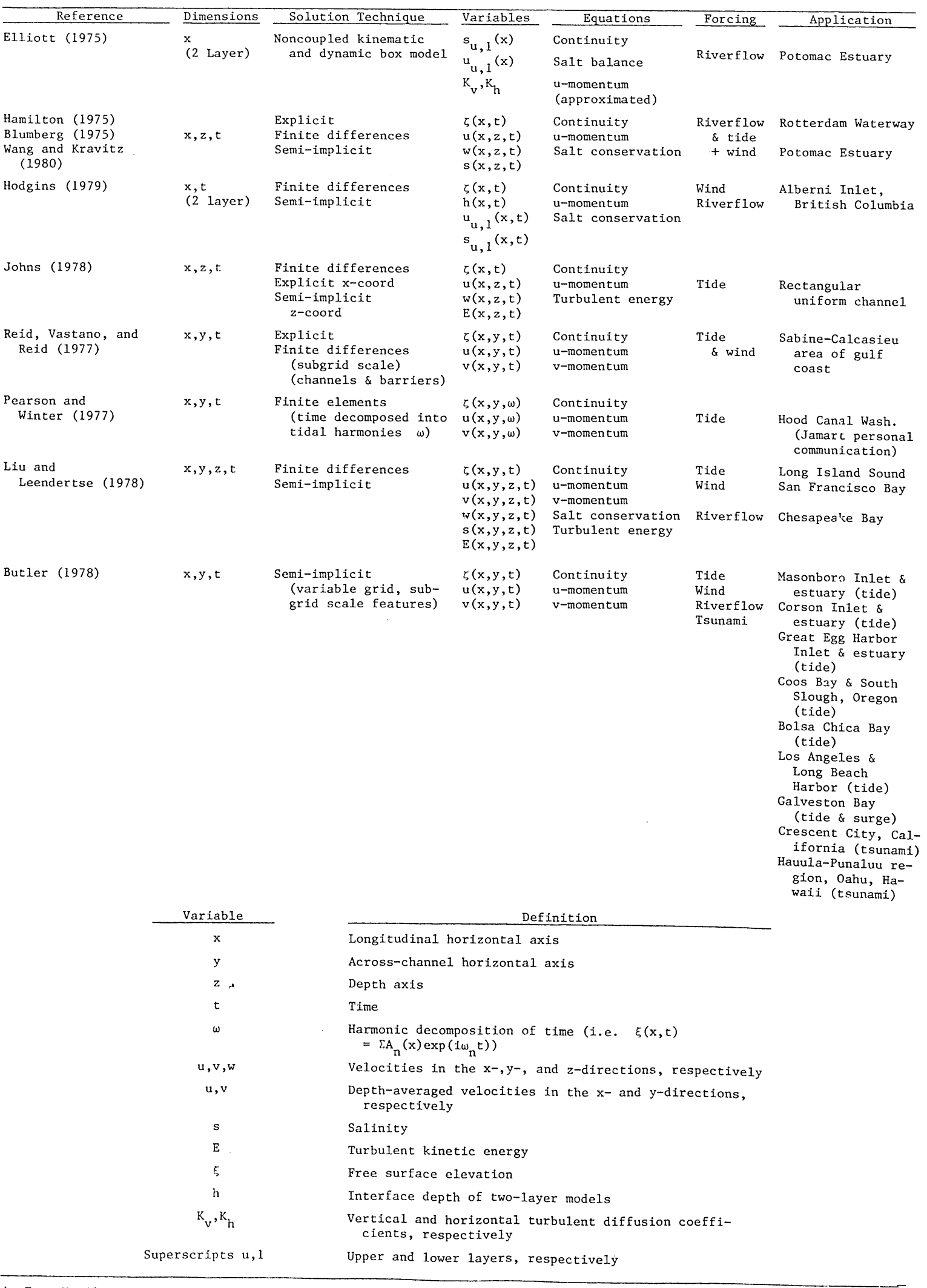

* From Hamilton and Fucik (1980). 
Table 4

Representative Types of Water Quality Models of Estuaries*

\begin{tabular}{|c|c|c|c|c|c|}
\hline Reference & $\begin{array}{c}\text { Hydrodynamic Cfrculation } \\
\text { Submode } 1^{\star \star}\end{array}$ & $\begin{array}{l}\text { Water Quality } \\
\text { State Var1ables } \\
\end{array}$ & Kinetics and Comments & Forcing & Application \\
\hline $\begin{array}{l}\text { Barrett and } \\
\text { Mollowney (1972) }\end{array}$ & $\begin{array}{l}\text { 1-D tidally averaged } \\
\text { box model }\end{array}$ & $\begin{array}{l}\text { Organic carbon, organic } \\
\text { nitrogen, ammonia, } \\
\text { nitrate, Do }\end{array}$ & $\begin{array}{l}\text { L1near } \\
\text { Anerobic kinetics in- } \\
\text { cluded when } D 0<5 \% \\
\text { saturation }\end{array}$ & $\begin{array}{l}\text { Tidal amplitude, } \\
\text { riverflow, wind, } \\
\text { carbonacous and } \\
\text { nitrogenous loads, } \\
\text { temperature }\end{array}$ & $\begin{array}{l}\text { Thames Estuary } \\
(\text { U.K.) }\end{array}$ \\
\hline $\begin{array}{l}\text { Nihoul et al. } \\
\text { (1979) }\end{array}$ & $\begin{array}{l}\text { 1-D time-dependent } \\
\text { dynamic transport } \\
\text { dispersion model }\end{array}$ & $\begin{array}{l}\text { Do, nitrate, ammonia, } \\
\text { iron, manganese }\end{array}$ & $\begin{array}{l}\text { Thermodynatic equilibrium } \\
\text { assumed. Redox poten- } \\
\text { tials control reaction } \\
\text { rates assumed to be due } \\
\text { to bacterial activity } \\
\text { Highly polluted - no } \\
\text { nutrient limitation }\end{array}$ & Tide, riverflow & $\begin{array}{l}\text { Scheldt } \\
\text { (The Netherlands) }\end{array}$ \\
\hline $\begin{array}{l}\text { Leendertse and } \\
\text { Gritton (1971) }\end{array}$ & $\begin{array}{l}\text { 2-D (horizontal) } \\
\text { time-dependent } \\
\text { dynamic transport- } \\
\text { dispersion model }\end{array}$ & $\begin{array}{l}\text { Coliforms, salinity (chlo- } \\
\text { rides), DO-BOD }\end{array}$ & Linear & $\begin{array}{l}\text { Tide, fresh and } \\
\text { storm drain flow, } \\
\text { BOD load, wind }\end{array}$ & $\begin{array}{l}\text { Jamaica Bay } \\
\text { (N.Y.) }\end{array}$ \\
\hline $\begin{array}{l}\text { Chen and Orlob } \\
(1972)\end{array}$ & $\begin{array}{l}\text { 1-D time-dependent } \\
\text { link-node dynamic } \\
\text { transport-dispersion } \\
\text { model }\end{array}$ & $\begin{array}{l}\text { Temperature, salinity, } \\
\text { ammonia nitrogen, } \\
\text { nitrate nitrogen, } \\
\text { phosphorus, Do-BOD, } \\
\text { algae (2), t zooplank- } \\
\text { ton, fish (2) }\end{array}$ & Linear and Monod & $\begin{array}{l}\text { Tide, riverflow, } \\
\text { waste and nutrient } \\
\text { loads, wind, light }\end{array}$ & $\begin{array}{l}\text { San Francisco Bay } \\
\text { Delta System }\end{array}$ \\
\hline $\begin{array}{l}\text { Ditoro et a1. } \\
\quad(1977)\end{array}$ & $\begin{array}{l}\text { 1-D tidally averaged } \\
\text { transport-dispersion } \\
\text { model }\end{array}$ & $\begin{array}{l}\text { Do-BOD, phosphorus (or- } \\
\text { ganic and inorganic), } \\
\text { silica, nitrogen (ni- } \\
\text { trate, ammonia, organic), } \\
\text { phytoplankton, zooplank- } \\
\text { ton }\end{array}$ & Linear and Monod & $\begin{array}{l}\text { Tide, riverflow, } \\
\text { wind, temperature, } \\
\text { light, carbonacous } \\
\text { and nitrogenous } \\
\text { waste loads }\end{array}$ & $\begin{array}{l}\text { San Francisco } \\
\text { Bay-Delta System } \\
\text { Potomac Estuary }\end{array}$ \\
\hline $\begin{array}{l}\text { Dah1-Madsen } \\
\quad(1978)\end{array}$ & $\begin{array}{l}\text { Box models or } 1-\mathrm{D} \text { time- } \\
\text { dependent transport- } \\
\text { dispersion model }\end{array}$ & $\begin{array}{l}\text { Phytoplankton (carbon, ni- } \\
\text { trogen, phosphorus), zoo- } \\
\text { plankton (carbon), detri- } \\
\text { tus (carbon, nitrogen, } \\
\text { phosphorus), inorgan1c } \\
\text { nitrogen, inorgan1c } \\
\text { phosphorus, Do-BoD, } \\
\text { sed ment carbon }\end{array}$ & Linear and Monod & $\begin{array}{l}\text { Riverflow, tide, } \\
\text { temperature, } \\
\text { light, nutrient, } \\
\text { and organic loads }\end{array}$ & $\begin{array}{l}\text { Various Danish fjords } \\
\text { and estuaries } \\
\text { Principally } \\
\text { Limfjorden }\end{array}$ \\
\hline $\begin{array}{l}\text { Seip (1979) } \\
\text { and Sefp ete al: } \\
(1979)\end{array}$ & $\begin{array}{l}\text { None (observed hydro- } \\
\text { graphle teglite used } \\
\text { as forcing for four- } \\
\text { layer, four horizon- } \\
\text { tal section model) }\end{array}$ & $\begin{array}{l}\text { Benthic algae (8 age } \\
\text { (1asseg), blomass, zine, } \\
\text { fron }\end{array}$ & $\begin{array}{l}\text { Model of population } \\
\text { dynatiles with toxlelty= } \\
\text { related mortality }\end{array}$ & $\begin{array}{l}\text { Jight, salinity, } \\
\text { tefiperature, } h 1= \\
\text { trogen ( } 1 \text { imiting } \\
\text { nutrient) }\end{array}$ & $\begin{array}{l}\text { Hardanger fjord } \\
\text { Sorf forden } \\
\text { Trondheims fjorden } \\
\text { (Norway) }\end{array}$ \\
\hline
\end{tabular}

* From Hamilton and Fucik (1980).

** $\quad I-D=$ one dimensional; $2-D=$ two dimensional.

+ Numbers in parentheses indicate the number of simulations available. 
Table 5

Representative Estuarine Water Quality Models Available With User Documentation

\begin{tabular}{|c|c|c|c|}
\hline Mode1 & References & $\begin{array}{c}\text { Hydrodynamic Circulation } \\
\text { Submodel } \\
\end{array}$ & $\begin{array}{l}\text { Water Quality } \\
\text { State Variables } \\
\end{array}$ \\
\hline SEM & Hydroscience, Inc. (1971, 1972) & $1-D$ tidally averaged & $\mathrm{DO}-\mathrm{BOD}$ \\
\hline ES001 & $\begin{array}{l}\text { Chapra and Gordimer (1973a, } \\
\text { 1973b) }\end{array}$ & 1-D tidally averaged & DO-BOD \\
\hline DEM & $\begin{array}{l}\text { Feigner and Harris (1970) } \\
\text { Callaway, Byram, and Ditsworth } \\
\quad(1969) \\
\text { Callaway and Byram (1970) } \\
\text { Water Resources Engineers } \\
\quad(1974)\end{array}$ & $\begin{array}{l}\text { 1-D time-dependent link-node } \\
\text { transport-dispersion } \\
\text { model }\end{array}$ & $\begin{array}{l}\text { DO-BOD, temperature, } \\
\text { algae, nitrogen, phos- } \\
\text { phorous, coliforms, } \\
\text { TDS, * heavy metals (2), } \\
\text { pesticides (2) }\end{array}$ \\
\hline RECEIV & $\begin{array}{l}\text { Metcalf and Eddy, Inc., } \\
\text { University of Florida, and } \\
\text { Water Resources Engineers, } \\
\text { Inc. (1971) }\end{array}$ & & $\begin{array}{l}\text { DO-BOD, four conserva- } \\
\text { tive or nonconserva- } \\
\text { tive (first-order } \\
\text { decay) constituents }\end{array}$ \\
\hline RIVSCI & $\begin{array}{l}\text { Systems Control, Inc., and } \\
\text { Snohomish County Planning } \\
\text { Department (1974) }\end{array}$ & & $\begin{array}{l}\text { DO-BOD, temperature, } \\
\text { total and fecal coli- } \\
\text { forms, nitrogen, phos- } \\
\text { phorus, copper, lead, } \\
\text { two conservative } \\
\text { constituents }\end{array}$ \\
\hline ESTECO & $\begin{array}{l}\text { Texas Water Development Board } \\
\quad(1977)\end{array}$ & $\begin{array}{l}\text { 2-D (horizontal) time- } \\
\text { dependent transport- } \\
\text { dispersion model }\end{array}$ & $\begin{array}{l}\text { DO-BOD, temperature, } \\
\text { algae (2), nitrogen, } \\
\text { phosphorus, coliforms, } \\
\text { detritus, alkalinity, } \\
\text { TDS, zooplankton, } \\
\text { benthos, pH, carbon, } \\
\text { fish (3) }\end{array}$ \\
\hline
\end{tabular}

